\title{
The Paulo Afonso Falls by Castro Alves (1847-1871): Interweaving Poetry and Social Imaginaries
}

\begin{abstract}
This article explores the aspect of visuality in the poetic work A Cachoeira de Paulo Afonso [The Paulo Afonso Falls] by Castro Alves (1876) from the perspective of its dialogue with the pictorial and political construct of the Paulo Afonso Falls in the Brazilian social imaginaries of the nineteenth century. Through the analysis of the photographic representation of Cachoeira de Paulo Afonso [Paulo Afonso Falls] by August Stahl (1860) and an excerpt from Alves's dramatic poem, I present a comparative reading centred on the mechanisms of visuality and persuasion employed in both media, taking into account their relationship to the social problem of slavery and the issue of the human right to freedom.
\end{abstract}

Keywords: Brazilian poetry, Castro Alves, enargeia, iconography, slavery, social imaginaries

One of Antonio de Castro Alves's least studied poetic works, A Cachoeira de Paulo Afonso [The Paulo Afonso Falls], written between 1868 and 1870, features the human tragedy of slavery throughout its thirty-three poems, displaying a variety of dramatic devices so as to persuade the reader/listener to support the abolitionist cause. ${ }^{1}$ Until the beginning of the twenty-first century, A Cachoeira de Paulo Afonso had received relatively little attention in publications and academic papers, with Affonso Romano de Sant'Anna's brief analysis in $O$ canibalismo amoroso (1984) being one of the few studies dedicated to the poem. Nonetheless, the several mentions of the poem in critiques of Castro Alves's oeuvre have highlighted the poem's imaginative quality - exceptionally plastic and musical derived from a poetic sensibility affected by landscape. ${ }^{2}$ The emphasis on the

1 This article synthesizes the main argument of my master's thesis (Gobbi Alves Araújo 2015). An earlier version of this paper was presented at the 2016 ICLA conference in Vienna. I would like to thank the seminar's organizers and participants for their comments. Moreover, I am grateful to Prof. Thomas O. Beebee for his valuable suggestions. This study was financed in part by the Coordenação de Aperfeiçoamento de Pessoal de Nível Superior - Brasil (CAPES) - Finance Code 001. 2 Some authors who have highlighted the sensory aspect of Alves's poetry and its particular interest in the Brazilian landscape are Manuel Bandeira (1946), Eugênio Gomes (1953), Fausto Cunha (1971), and Jon M. Tolman (1975).

Ә Open Access. (C 2021 Giovanna Gobbi Alves Araújo, published by De Gruyter. (๔) BY-NC-ND This work is licensed under the Creative Commons Attribution-NonCommercial-NoDerivatives 4.0 International License. https://doi.org/10.1515/9783110642056-026 
Brazilian landscape was then seen, by some scholars, as an attempt to value local character or as a patriotic gesture. However, the geographical features selected by the author, as I will argue, symbolically engage cultural and political issues of Alves's time by putting a spotlight on an icon of the legitimation of the monarchical regime. Hence, this article aims to examine the symbolic construction of the Second Empire in the social imaginaries of nineteenth-century Brazil, through travel reports and iconographic material about the Paulo Afonso Falls, and its later subversion in Romantic literature by the abolitionist poet Castro Alves.

\section{The symbolic construct of the Paulo Afonso Falls}

The landmark of the Paulo Afonso Falls, located on the border of the states of Bahia and Alagoas, was converted into a social construct and a visual paradigm in nineteenth-century Brazil due to specific historical and political conditions that underlay its symbolic configuration.

In the 1850s, imperial sovereignty was threatened by a decline in political support from north-eastern authorities and major landowners. Right after a period of political turmoil with the Praieira Revolt that shook the province of Pernambuco from 1848 to 1850, a rural oligarchy felt discontented as a result of the promulgation of the Eusébio de Queirós Act and the Land Law, which were passed in 1850. The first law abolished the transatlantic slave trade, and the second instituted immigrant land tenure as a way of making up for the gradual decrease in slave labour. These events ended up undermining monarchical rule and stirring political unrest among northern landowners who now demanded decentralized policies and financial support. In 1859, Emperor Pedro II spent four months on a journey to the northern provinces aimed at, among other things, meeting these demands by instituting compensatory measures, such as the creation of Institutes of Agriculture in every province he visited and the granting of nobility titles to the local rural elites, thus "giving back in political status what was withdrawn in material interest," according to the historian José Murilo de Carvalho (2007, 258; my translation).

Moreover, the consequences of the Emperor's travels to the north were not only political; they were also of a symbolic nature. From the Emperor's travel memoirs, it is known that part of his duties during the journey included visiting hospitals, schools, and churches, donating to the poor, making speeches, and attending Masses and parades in his honour (Schwarcz 1998, 358) - symbolic acts that left an imprint on the Brazilian nineteenth-century social imagination, while strategically promoting a discourse of national unification in an attempt to consolidate the image of the Emperor and to ensure the maintenance of the 
monarchical regime. Considering that the foundation of every political regime entails the production of representations of the social order, in other words, a social imaginary as conceived by the philosopher Bronisław Baczko $(1985,309)$, the symbolic projection of the Emperor into the inland areas of Brazil would purposely serve to reinforce imperial hegemony.

In addition to such endeavours, Pedro II commissioned a number of hydrographic mapping expeditions to the São Francisco river, on which the Paulo Afonso Falls are situated, between 1850 and 1860, in order to ascertain navigability and expand business transactions. Because they had been an object of interest and concern on the part of the imperial power, the Emperor visited the Paulo Afonso Falls on the occasion of his visit to the northern provinces in October 1859. After the encounter with this "majestic scene" (Pedro II 2003, 135; my translation), the monarch hired a photographer to document the waterfall the following year. It was the German-Italian photographer Auguste Stahl who created a panorama of the Falls in 1860 that is an unparalleled milestone in the history of Brazilian iconography.

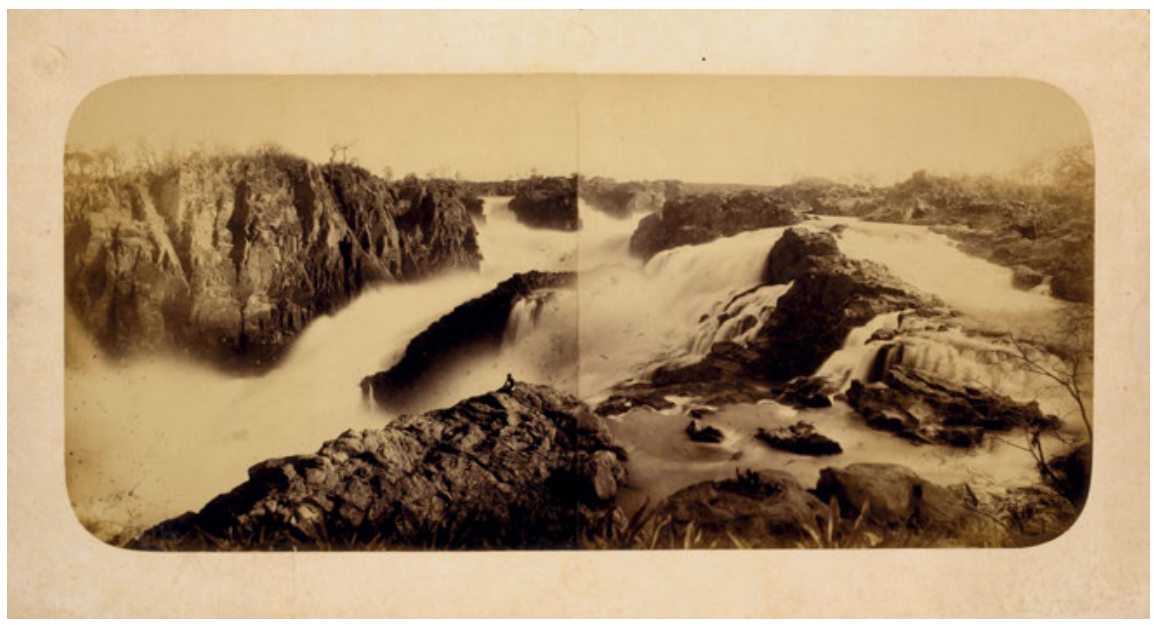

Fig. 1: Auguste T. C. Stahl. Stahl \& Cia., Fotógrafos de S. M. o Imperador do Brasil. Cachoeira de Paulo Afonso. c. 1860. D. Thereza Christina Maria Collection. Courtesy of Fundação Biblioteca Nacional.

The panorama called Paulo Afonso Falls depicts the point where the seven tributaries of the São Francisco river meet in an eighty-metre waterfall, displaying in the middle ground an Afro-Brazilian man against the turbulent torrent. One can clearly see the rock formations and the parched vegetation that make up a 
dramatic composition. The evident contrast between an incommensurable force of nature and human vulnerability accounts for the spectator's feeling of wonder and terror proceeding from, according to Immanuel Kant's theory of the sublime (1995, 103-104), both the subjective conflict between imagination and reason (given the magnitude beyond comparison of the waterfalls) and the acknowledgement of a supersensible vocation. In the Brazilian context of slavery, the incorporation of the Afro-Brazilian person - possibly an enslaved individual - in Stahl's artistic composition directly evokes the moral degradation of the condition of slavery. Because the foundation of the sublime is found within men, the feeling that emerges from the contradiction between our human faculties and the power of nature is responsible for subduing, even if momentarily, our imprisonment in the sensible world, restoring to the spirit its moral dignity. Consequently, the aesthetic judgement of Stahl's diptych can prompt a debate about slavery in nineteenth-century Brazil if we take into account the interconnection between the feeling of the sublime and the condition for its occurrence, that is, the consciousness of human moral freedom. The effectiveness of the sublime justifies the great impact of Stahl's panorama and the later reproduction of this model in subsequent artworks. As a matter of fact, after Stahl's panorama, visual representations of the Falls would flourish in the second half of the nineteenth century, including paintings by Herman Wahnschaffe (c. 1861) and E. F. Schute (c. 1860), an engraving by P. Skelton and R. Knight (1869), ${ }^{3}$ and photographs by Augusto Riedel (1869), Marc Ferrez (1875), and Ignácio Fernandes Mendo (1878).

If the iconographic representations of the Paulo Afonso Falls relied chiefly on the sublime style to convey the negative pleasure one feels when facing them, nineteenth-century travellers' written descriptions were no different. The Emperor's comment in one of his travel logs discloses the pathetic aspect of his encounter with the waterfalls: "Trying to describe the waterfall in a few pages, and fully, would be impossible, and I feel that time would only allow me to draw very imperfect sketches" (Pedro II 2003, 135-136; my translation). The rapture of the sublime experience justifies the impossibility of reporting such a "majestic scene." In a similar fashion, the French scientist Emmanuel Liais, a member of the Imperial Observatory of Rio de Janeiro, would remark on the fury of the flow ("les eaux furieuses"), which turned into a hurricane of water dust. In the "splendour of the spectacle" described by Liais (1866, 391; my translation) one can identify the hybrid feeling of dread and wonder that makes up the sublime experience. In 1867, when the English diplomat Richard Burton visited the Falls, he would

3 Published as the frontispiece of volume 2 of Richard Burton's Explorations of the Highlands of the Brazil (1869). 
describe a feeling of enchantment and awe too intense to bear provoked by the impetuous movement of the "liquid vastness": "And the marvellous disorder is a well-directed anarchy: the course and sway, the wrestling and writhing, all tend to set free the prisoner from the prison walls. Ces eaux! mais ce sont des âmes: it is the spectacle of a host rushing down in 'liquid vastness' to victory, the triumph of motion, of momentum over the immoveable" (Burton 1869, 444-445).

Note that the expression "marvellous disorder" embodies much of the feeling of discrepancy caused by the experience of the sublime. Burton's description of the torrent also conveys the notion of a battle between nature's titans in an anthropomorphic metaphor of the waters. Finally, it is important to add that Burton's superlative epithet to Paulo Afonso on the frontispiece, "King of rapids, the Niagara of Brazil," goes as far as to claim a sovereign status for the Falls, hence alluding to the Brazilian imperial regime and its initiatives to map and assess all of the São Francisco river's attributes.

In a broader sense, this brief selection of works may be evidence that the production of artistic and scientific records about the Paulo Afonso Falls in the mid-nineteenth century was not only affiliated with the monarchical state but also contributed to the renewal of the social imaginary related to the unity and legitimacy of the Empire - locally and abroad. Since "symbolic landmarks" turn into powerful ideas when they are used as support for the organization of the collective imagination, in accordance with Baczko (1985, 307), the monarchical state would gain similar status by attaching itself to the symbolic landmark of the Paulo Afonso Falls, allowing its presence to infiltrate the collective system of the social imagination.

In Benedict Anderson's study on the nationalist experience of imagined communities, he asserts that "thanks to print-capitalism, a sort of pictorial census of the state's patrimony becomes available, even if at a high cost to the state's subjects" $(2006,182)$, and argues that the possibility of its reproducibility is meant to reveal the "real power of the state" in a process which takes place even in post-independence states - as is the case with Brazil - and which he defines as "political museumizing” (183). In fact, all of the commissioned artworks and travel reports previously mentioned were published by the imperial printing press in luxurious editions, some in more than one language, and sent to European countries.

On the basis of such theoretical studies of the symbolic networks that constitute collective identities, I argue here that the Paulo Afonso Falls can be understood as a visual framework for a national aesthetic whose historic invention generated an allegory of the Brazilian Empire. This is the narrative and pictorial tradition of representing national ideas with which Castro Alves establishes a dialogue when he chooses the Paulo Afonso Falls as the natural setting for the poetic representation of slavery eleven years after the Emperor's visit to the location. 


\section{Alves's dramatic poem}

Published five years after the poet's death, in 1876, Castro Alves's book is - not by coincidence - entitled A Cachoeira de Paulo Afonso (Alves 1997, 311-373), and tells the plight of an enslaved couple, Lucas and Maria, who try to keep their dignity while facing the atrocities of the slave system. Essentially, the narrative exposes a crime of rape committed by an enslaver's son against Maria, an enslaved Black woman. Violence changes everything within and around her. It taints the natural landscape, making the idyllic environment gradually exhibit signs of evil and brutality. Facing dishonour and the subsequent impossibility of love's fruition, Maria and her partner commit suicide on a canoe that launches them off the Falls. In the poem's final verses, the enslaved couple's suicide is represented by the metaphor of a transcendent union, in which natural elements celebrate, at once, their wedding, their funeral, and their final communion with the cosmos.

Throughout Alves's poem, the metaphorical configuration of the natural setting stages the tragic drama of slavery with graphic vividness and sublimity. Far from being a mere landscape ornament, the water element plays a prominent and active role in the symbolization of conflicting human forces.

Castro Alves's depiction of Paulo Afonso echoes both the travellers' descriptions and the artists' pictorial representation of the São Francisco waters, as it extensively employs visualizing techniques (enargeia) and descriptive procedures (ekphrasis) in the characterization of elements of nature in order to generate pathos in readers and listeners, contributing to the rhetorical functions of delighting, teaching, and moving in favour of the abolitionist cause.

As stated by the scholar Heinrich Plett, enargeia is the visual effect obtained from the use of rhetorical techniques through which the poet creates "imaginary scenes," providing immediacy and concreteness to any narrated event. The effect is such as if the scene were happening before the eye of the recipient; yet the effect of presence takes place before the inner eye of the imagination (Plett 2012, 12). The effectiveness of enargeia depends on the concreteness of descriptive details (circumstantiae) to make a discourse more vivid, such as figures of speech, bright discourse, monologue, dialogue, and ekphrasis. Discussed by Aristotle, Cicero, Quintilian, and Longinus, among others, enargetic techniques were widely explained in manuals of rhetoric used in educational institutions throughout the 1800s, being the "foundation stone" of poetics in nineteenth-century Brazil, according to Fausto Cunha (1971, 65; my translation). As a means to attain an aesthetic sublime effect, the use of enargeia is crucial for enhancing the persuasiveness of a poetic text, and even more relevant when placing the theme of slavery before the inner eyes of the audience. 
For the purposes of illustration, I will briefly discuss some of these strategies in the poem "A Cachoeira" [The Waterfall] (Alves 1997, 365-366), located in the final segment of $A$ Cachoeira de Paulo Afonso. The poem is characterized by the overlapping of three symbolic layers. It begins with a metaphorical event in which a bull becomes prey to a snake and is unable to resist the attack. The reptile drags the calf into the waters after biting and crushing it to the last bone. The hunting scene resonates with the same irrepressible violence seen in the sexual attack on Maria, mirroring that brutal experience. Then, the lyric I transposes the assault metaphor to describe the waterfalls portrayed as a clash of natural forces: the waters - "infinite serpent" - against rock formations transmuted into a "black granite bull" (365; my translation) - somewhat comparable to the ekphrastic description by Richard Burton. In the confrontation between the two majestic opponents, the watercourse takes on attributes of a herd of horses: it gallops, rears, and rides, convulsively, from the top of the cliff. In this second stage, the zoomorphism of the waterfalls expands and magnifies distinctive traits of both rivals. The enargetic configuration attains vividness with the aid of metaphors of movement, accurate word choice, and alliterations that materialize the waterfall, replicating bursts of water through the verses. In a third and final step, the process of metaphorization of the waters enters a mythological stage, in which the opponents acquire anthropomorphous components as mythological creatures centaur and giant - who sustain the stream that flows over their shoulders.

At the poem's climax, the waters of the São Francisco River enact the battle of Laocoön and his sons against the serpents of Tenedos, materialized in a wellknown statue dated to the first century BC, transposing the sexual assault on Maria into a metaphorical clash of natural forces. The physical suffering of the family members is depicted by the contraction of Laocoön's fist, his suffocated expression, and the imprisonment of his children around the reptiles' rings.

\author{
Ferocious Laocoön's colossal group \\ Hail to Greece beyond and the unearthly battle! ... \\ Cleric's fist and the violet front ... \\ And the serpents of Tenedos enraged! ... \\ For reptile - a river! For prophet - a hill! \\ For Minerva's altar - a mountain! \\ Around the pedestal hunted, betrayed, \\ Like children - weeping - the rocks! ... (Alves 1997, 366; my translation)
}

Through highly visual terminology, the lyric I synthesizes earlier metaphorical progressions in applying rhetorical techniques related to the categories of clarity, sharpness, and brightness in the imaginative view of the Greek statue, reaching the pinnacle of the aesthetic sublime and the poem's highest point. Within the 
poem, the ekphrasis of Laocoön's statue embodies the wrestling of the natural forms; it provides an aesthetic treatment of the poem's tragic matter; and, philosophically, it refers to the eighteenth-century debates on human freedom set forth by Winckelmann, Lessing, and, later on, Schiller. According to Schiller, “one single sublime emotion often suffices to break all this tissue of imposture, at one blow to give freedom to the fettered elasticity of spiritual nature, to reveal its true destination, and to oblige it to conceive, for one instant at least, the feeling of its liberty" (1902, 131). The presence of Laocoön conjures up the affirmation of the human spirit's superiority in the face of any imposition from the sensible realm, since the aesthetic expression of the pain of Laocoön and his sons dignifies their struggle. If the enargetic discourse works so as to stimulate pathos, the ekphrastic visual description of Laocoön symbolizes the existing violence of the human sphere as a way of representing the moral corruption of the enslaved person and denouncing the horrors of the slaveholding system. Hence, the ekphrastic visual description of Laocoön not only evokes existing violence - which was the foundation of the Brazilian social sphere in the nineteenth century - but also stands in the poem as an allegory of human dignity. In this context, the visualizing effects of enargeia act to enhance the persuasiveness of the poetic text, illuminating the argument against slavery.

\section{Intertextual and paratextual elements of A Cachoeira de Paulo Afonso}

Faced with a context of social exclusion, Alves seems to mobilize persuasive devices related to poetic visuality so as to dignify the enslaved individual through aesthetic elevation.

This procedure is not an isolated event in Brazilian literature, for it echoes the mythical elevation of indigenous figures performed by Gonçalves de Magalhães and Gonçalves Dias - twenty years before Alves's time - during the Indianist movement, which shaped nationalism by forging noble ancestors to the Brazilian people. Both Magalhães's and Dias's poetic works exalt epic accomplishments of Native groups, painting vivid pictures of war-like conflicts in which natural elements enact heroic battles, often denouncing the Portuguese-Brazilian imperial policies of local oppression and indigenous extermination, as the critic David Treece (2000) points out in his study on the Brazilian Indianist movement.

In Alves's account of national history, violence against enslaved individuals serves to denounce the horrors of the slaveholding system once it exposes the bedrock of Brazil as a nation: the genocide and marginalization of its non-white 
population (Treece 2000,131). In a society where enslaved people were obliterated by social indifference, the attribution of heroic protagonism to Afro-Brazilians in a poem of an elevated tragic essence defies a certain tradition of literary models in which Black characters were either non-existent or the source of trouble for white heroes. Nevertheless, the effects of this protagonism are not only of a literary nature. Placing the human drama of slavery into a natural setting so closely linked to imperial power resulted in substantiating the complicity of the official political regime in the perpetuation of the institution of slavery.

In light of Gérard Genette's theoretical propositions in Seuils (1987), two paratexts related to the publication of $A$ Cachoeira de Paulo Afonso support this argument. Firstly, the postface to the text in the poet's manuscript contains a piece of news on the Emperor's 1859 visit to the Falls. If read in conjunction with Alves's republican poems, this appendix to the work may reinforce the poet's political opposition to the monarchical acts supporting the maintenance of slavery throughout the 1850 s and, therefore, corroborate the interpretation that the choice of the Paulo Afonso Falls as a setting for the poem may be related to the imperial invention of the location as an allegory of the Brazilian Empire, an empire founded on the misery of enslavement. Secondly, in an 1867 letter, Alves would disclose his plan to visit the Paulo Afonso Falls in order to complete the writing of his book and "be Chateaubriand in this other Niagara” (Alves 1997, 746; my translation). Taking into account the centrality of Chateaubriand's cultural authority in French romanticism and the key role of René and Atala in shaping the New World's national sensitivities, in accordance with Renata Wasserman's work (1989) on the discourse of the exotic in Atala, my reading argues that Alves's A Cachoeira de Paulo Afonso may have been devised as a national poem that challenges the official configuration of social imaginaries related to the Brazilian Empire and attempts to reframe national consciousness with respect to the abolition of slavery.

Alves's poetic drama takes advantage of the network of symbolic meanings evoked by the waterfall and constructed by the visual arts and travel literature, to thematize the brutal violence inflicted on the enslaved characters, modulating subsequent readings of cultural products related to the destructive power of the Falls. The critic Marcus Wood identifies a commonality of impression between Alves's poetic work and the iconographic pieces that preceded and succeeded it, which changed how the iconography related to the waterfall would be interpreted under the retroactive influence of his "explosive verses": "Because of the power and influence of Alves's masterpiece, the Falls were thenceforth saturated in an ecstatic yet tragic relation to slavery. The Falls became symbolically complicated, fraught, darker, more ambiguous, and finally more inspirational, because of the manner in which Alves had imaginatively commandeered the natural phenomenon" (Wood 2013, 255). 
On that account, it is productive to read the recapturing of the image of the Paulo Afonso Falls by Castro Alves in light of a narrative and pictorial tradition of representing national ideas. Narrative, because it follows the development of travel narratives and landscape descriptions, heightened after the European artistic contributions of 1816 and 1817; pictorial, because it witnesses a shift in the representation of the Paulo Afonso Falls from the linguistic field to that of the visual arts as well as an iconographic profusion in the 1800s, largely derived from contact with technological innovations in photography. Therefore, as Castro Alves centres the tragic drama of enslaved characters by the Paulo Afonso Falls, it is critical to consider the eponymous poem in relation to the network of meanings articulated by the social imaginaries of its time, taking into account a broader social and political context.

In conclusion, in A Cachoeira de Paulo Afonso, Castro Alves seems to subvert the referent of a national aesthetic by choosing the Paulo Afonso Falls to stage the tragic drama of slavery. Inserted in a narrative and pictorial tradition of symbolic representation of national issues, Castro Alves's book presents the Falls as a metaphor for slave freedom and a national icon related to social liberation, thus challenging the order of visibilities in the final decades of the monarchical era.

\section{Works cited}

Alves, Castro. Obra completa. Rio de Janeiro: Nova Aguilar, 1997.

Anderson, Benedict. Imagined Communities. London: Verso, 2006.

Baczko, Bronisław. “A imaginação social.” Trans. Manuel Villaverde Cabral. Enciclopédia Einaudi: Anthropos-Homem. Vol. 5. Lisbon: Imprensa Nacional; Casa da Moeda, 1985. 296-332.

Bandeira, Manuel. Apresentação da poesia brasileira seguida de uma antologia de poetas brasileiros. Rio de Janeiro: Casa do Estudante do Brasil, 1946.

Burton, Richard. Explorations of the Highlands of the Brazil. Vol. 2. London: Tinsley Brothers, 1869.

Carvalho, José Murilo de. A construção da ordem: A política imperial, Teatro de sombras: $A$ política imperial. 3rd ed. Rio de Janeiro: Civilização Brasileira, 2007.

Cunha, Fausto. O Romantismo no Brasil: De Castro Alves a Sousândrade. Rio de Janeiro: Paz e Terra, 1971.

Gobbi Alves Araújo, Giovanna. "The Painting of the Waters: A Study on Poetic Visuals in $A$ Cachoeira de Paulo Afonso by Castro Alves.” MA thesis. University of São Paulo, 2015.

Gomes, Eugênio. Prata de casa. Rio de Janeiro: Editora A Noite, 1953.

Kant, Immanuel. Crítica da faculdade do juízo. Trans. Valerio Rohden and António Marques. 2nd ed. Rio de Janeiro: Forense Universitária, 1995.

Liais, Emmanuel. “Le San Francisco au Brésil.” Bulletin de la Société de géographie 5th ser. 11 (January-June 1866): 390-402. 
Pedro II. Imperador do Brasil. Viagens pelo Brasil: Bahia, Sergipe, Alagoas, 1859/1860. Introd. and notes Lourenço Luiz Lacombe. 2nd ed. Rio de Janeiro: Bom Texto; Letras \& Expressões, 2003.

Plett, Heinrich F. Enargeia in Classical Antiquity and the Early Modern Age: The Aesthetics of Evidence. Leiden and Boston: Brill, 2012.

Schiller, Friedrich. Aesthetical and Philosophical Essays. Ed. Nathan Haskell Dole. Vol. 1. Boston: Niccolls, 1902.

Schwarcz, Lilia Moritz. As barbas do imperador: D. Pedro Il, um monarca nos trópicos. São Paulo: Companhia das Letras, 1998.

Tolman, Jon M. “Castro Alves, poeta amoroso." Revista do Instituto de Estudos Brasileiros 17 (1975): 27-49.

Treece, David. Exiles, Allies, Rebels: Brazil's Indianist Movement, Indigenist Politics, and the Imperial Nation-State. Westport and London: Greenwood Press, 2000.

Wasserman, Renata R. M. “Chateaubriand's Atala and the Discourse of the Exotic." Dispositio 14.36/38 (1989): 39-67.

Wood, Marcus. Black Milk: Imagining Slavery in the Visual Cultures of Brazil and America. Oxford: Oxford University Press, 2013.

Giovanna Gobbi Alves Araújo is a PhD candidate in Brazilian Literature at the Universidade de São Paulo, Brazil, and a Fulbright Visiting Research Student at the University of North Carolina at Chapel Hill. Her research, funded by CNPq and Fulbright, focuses on the analysis of vivid description in nineteenth-century Brazilian epic poetry and the writing of national history. 
